\title{
ФОРМУВАННЯ ГРАФІЧНОЇ КОМПЕТЕНТНОСТІ МОЛОДШИХ СПЕЦІАЛІСТІВ ЧЕРЕЗ ТЕХНОЛОГІЇ ДИСТАНЦІЙНОГО НАВЧАННЯ
}

Воронцова І. В., Лук'янець В. Д., Шумська Л. П. Формування графічної компетентності молодших спеціалістів через технології дистанційного навчання.

У статті розкрито теоретико-методичні основи організації дистанційного навчання як одного із вагомих чинників педагогічної взаємодії викладача і студента. Проаналізовано дидактичні можливості дистанційного курсу 3 креслення у формуванні графічної компетентності молодших спеціалістів.

Ключові слова: дистанційне навчання, дистанційні курси, дистанційна освіта, компетентнісний підхід, графічна компетентність.

Воронцова И. В., Лукьянец В. Д., Шумская Л. П. Формирование графической компетентности младших специалистов через технологии дистанционного обучения.

В статье раскрыты теоретико-методические основы организации дистанционного обучения как одного из весомых факторов педагогического взаимодействия преподавателя и студента. Проанализированы дидактические возможности дистанционного курса по черчению в формировании графической компетентности младших специалистов.

Ключевые слова: дистанционное обучение, дистанционные курсы, дистанционное образование, компетентностный подход, графическая компетентность.

Vorontsova I. V., Lukyanets V. D., Shumskaya L. P. Formation of graphic competence of junior professionals through distance learning technologies.

The article deals with the theoretical and methodological foundations of distance learning as one of the important factors of pedagogical cooperation of the teacher and the student. The article analyzes the possibilities of a distance course on technical drawing in the forming of graphical competence of junior specialists.

Key words: Distance learning, distance courses, distance education, competence approach, graphical competence.

Швидкі темпи розвитку інформатизації суспільства, докорінні зміни в соціальноекономічній та політичній сферах життя в Україні призводять до необхідності модернізації системи навчання у вищих навчальних закладах.

На сучасному етапі якість освіти - тема більшості дискусій у світових освітніх спільнотах. Завданням вищого навчального закладу є «підвищення якості вищої освіти шляхом ऑii фундаменталізації, інформування студентів про сучасні досягнення науки i техніки, забезпечення спрямованості навчання на нові інформаційні технології; забезпечення доступності освіти; орієнтація на активність, самостійність, творчість, індивідуальність особистості студента; забезпечення засобами для мобільності студентів, диверсифікації навчання» [2, с. 12].

Усім цим вимогам відповідає дистанційне навчання, яке значною мірою зумовлюється процесами оптимізації навчального процесу та потребами формування позитивних умов для індивідуального розвитку молоді, іiі соціалізації та самореалізації.

Meта статті: проаналізувати дидактичні можливості дистанційного курсу 3 креслення у формуванні графічної компетентності молодших спеціалістів. 
Дистанційна освіта, яка є наслідком об’єктивного процесу інформатизації, зараз вважається однією 3 найбільш перспективних та інтегральних форм навчальної діяльності загалом розвитку людини.

Важливим ресурсом у забезпеченні дистанційної освіти $є$ інноваційна діяльність навчального закладу, спрямована, насамперед, на досягнення нової, сучасної якості освіти, на розв'язання пріоритетних завдань оновлення змісту та технологій навчання і виховання, які раціонально поєднують інформативні та активні методи навчання, надають доступ до мереж високоякісних баз даних, розширюють можливості студентів до сприйняття складної інформації, активізують їх самостійну когнітивну діяльність тощо.

Проблема організації дистанційного навчання в різних типах навчальних закладів все більше привертає увагу як вітчизняних, так і зарубіжних дослідників, що зумовлено пошуком інноваційних підходів до організації процесу педагогічної взаємодії як у системі стосунків викладач - студент (учень), так і викладачпедагогічний колектив, викладач - батьки, викладач - адміністрація.

Теоретико-методологічні основи організації дистанційного навчання досліджувалися С. Гончаренко, І. Зязюном, Н. Ничкало, І. Підласим; дидактичні основи дистанційного навчання представлені у працях В.Галузинського, М. Махмутова, П. Юцявічене; психологічні основи системи дистанційного навчання розглядалися Л. Виготським, П. Гальперіним, Н. Тализіною.

Розвитку наукових досліджень 3 проблеми дистанційного навчання та його впровадженню у педагогічний процес присвячені праці вітчизняних та зарубіжних науковців: А. Андреєва, В. Бикова, Є. Долинського, Н. Думанського, М. Жалдака, Р. Іващенко, О. В. Кареліної, В. Кременя, В. Кухаренко, В. Осадчого, А. Петрова, Е. Полата, Н. Рибалко, О. Рибалко, Л. Романишиної, В. Сиротенка, С. Сисоєвої, П. Стефаненка, В. Тихомирова, А. Хуторського та ін.

У контексті організації підготовки молодших спеціалістів у Полтавському нафтовому геологорозвідувальному технікумі Полтавського національного технічного університету імені Юрія Кондратюка дистанційне навчання перебуває на етапі активного становлення та запровадження в навчально-виховний процес: розв'язано питання технічного забезпечення організації дистанційної мережі, розробляються методичні аспекти створення дистанційних курсів та навчально-методичних комплексів, розглядаються можливі шляхи та варіанти практичної організації дистанційних занять, вирішуються інші теоретичні та практичні питання, пов'язані 3 масовим упровадженням у навчальний процес дистанційних курсів навчання. Дистанційний курс розглядається нами як інформаційний продукт, що є достатнім для забезпечення дистанційного навчання за окремою навчальною дисципліною.

Дистанційні курси дисциплін, що розміщені на сайті системи дистанційного навчання технікуму, утворюють єдиний електронний веб-портал, створений на базі сучасної системи управління дистанційним навчанням- MOODLE, на якому містяться програми навчальних дисциплін, підручники, методичні вказівки, нормативно-довідкова література, інтерактивні тести, питання до заліків та екзаменів, теми курсових робіт і багато інших матеріалів в електронному форматі, систематизованих за окремими навчальними дисциплінами.

Інтерфейс дистанційних курсів дозволяє 3 легкістю знаходити потрібний матеріал та використовувати його; а сучасні технології, задіяні при створенні курсів, дозволяють користуватися ними з будь-якого пристрою, який має доступ до мережі Інтернет.

Дистанційні курси дозволяють використовувати різноманітні форми подання 
навчальних матеріалів: а) друкарські матеріали; б) відео - комп'ютерні фільми, відеоролики; в) аудіо - записані аудіоматеріали; г) засоби мультимедіа.

Технічна реалізація дистанційних курсів $\epsilon$ досить складним програмноапаратним комплексом. 3 програмним забезпеченням працює кілька категорій користувачів: викладачі; студенти; автори навчальних курсів; менеджери, адміністратори. Створення й упровадження дистанційних курсів розширює й поновлює роль викладача, який координує пізнавальний процес, постійно вдосконалює курси, що викладаються ним, підвищує творчу активність і кваліфікацію відповідно до нововведень та інновацій. Позитивно впливають дистанційні курси і на студента, підвищуючи його творчий i iнтелектуальний потенціали за рахунок самоорганізації, прагнення до знань, уміння взаємодіяти 3 комп'ютерною технікою і самостійно приймати відповідальні рішення. Цим актуалізується найважливіша функція навчального процесу в навчальному закладі - навчити майбутнього фахівця ефективно використовувати здобуті знання в практичній діяльності.

В умовах реалізації дистанційного навчання особливого значення набуває проблема компетентнісного підходу. Професійна компетентність молодшого спеціаліста нафтогазової галузі значною мірою визначається навичками роботи на певному обладнанні та 3 різноманітними матеріалами; вмінням одержати уявлення про технічний об'єкт або принципи його дії за конструкторською документацією, зафіксувати інформацію у графічній формі, використати графічне зображення 3 метою комунікації; соціальною й професійною мобільністю в умовах сучасного промислового виробництва за рахунок використання графічних засобів і методів, комп'ютерних графічних технологій. Виходячи з цього передумовою забезпечення високої функціональності майбутніх фахівців є належний рівень графічної підготовки, оскільки графічні знання і вміння $є$ засобом пізнання основ сучасного виробництва, сприяють загальнокультурному розвитку людини, її готовності до неперервної освіти і професійної діяльності [1, с. 7].

Недостатня сформованість у студентів умінь використовувати графічні зображення для опосередкованого пізнання дійсності, планування своїх дій, побудови процесу діяльності в образах та відтворення у графічній формі за допомогою комп'ютерних графічних продуктів знижує якість навчальної та майбутньої професійної діяльності, унеможливлює розв'язання творчих технічних задач [1, с. 40$]$.

О. Слободянюк вказує, що однією із форм реалізації відкритої освіти в навчанні графічних дисциплін $є$ дистанційне навчання, яке дає можливість здійснення навчального процесу за умови територіальної віддаленості його учасників і засобів навчання, а також забезпечення індивідуалізованої взаємодії між собою [3, с. 492].

Головний сенс удосконалення графічної підготовки у Полтавському нафтовому геологорозвідувальному технікумі полягає в тому, щоб створити і реалізувати такі умови, у яких студент не тільки накопичує знання і набуває необхідних навичок, але й гармонійно розвиває всі компоненти графічної компетентності, використовуючи сучасні засоби навчання, зокрема й інформаційно-телекомунікаційні технології. У цьому контексті актуальним стає дистанційне навчання як інформаційний засіб та потужна науково-педагогічна база навчання графічних дисциплін, упровадження якого відкриває значні можливості для творчого викладання креслення, забезпечує політехнічний принцип навчання, диференційований, системний, особистісно зорієнтований і компетентнісний підходи.

Для забезпечення процесу формування графічної компетентності молодших спеціалістів дистанційний курс поділений на блоки: інформаційний, змістовний i контрольно-моніторинговий (рис. 1). 


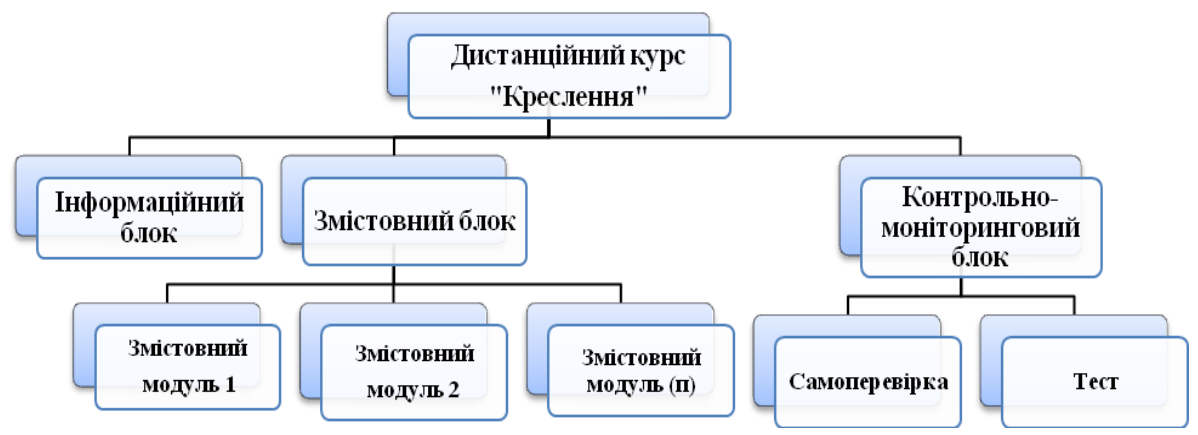

Рис. 1. Структура дистанційного курсу

В інформаційному блоці розміщено загальну інформацію про курс, літературу, посилання, програми, критерії оцінювання навчальних досягнень, глосарій. Змістовий блок, відповідно до робочої програми дисципліни, поділений на окремі елементи змістові модулі, які, у свою чергу, складаються з тем: лекційних, практичних та семінарських занять та питань, винесених на самостійне опрацювання (рис.2).

Вивчення матеріалу проходить послідовно. Спочатку студент опрацьовує теоретичний матеріал, а потім закріплює отримані знання, виконуючи практичну частину теми у вигляді графічних робіт, до яких передбачені методичні вказівки, індивідуальні завдання та зразки виконання.

Під час вивчення теми у студента $є$ можливість застосовувати інформаційні ресурси у графічному, ілюстративному та мультимедійному вигляді або проглянути інформацію з підготовлених викладачем посилань на веб-ресурси.

Такий підхід дозволяє сформувати у студентів уяву тривимірних узагальнених образів об'єктів та дає змогу забезпечити розвиток просторового мислення, розвивати науковий стиль мислення, формувати навички віртуального моделювання. Як зазначає М. Юсупова, активний розвиток просторового мислення під час вивчення графічних дисциплін засобами інформаційних технологій здійснюється у процесі моделювання, що «дає можливість візуально демонструвати на екрані монітора послідовні етапи розв'язання метричних і позиційних задач» [5, с. 110].

На нашу думку, процес моделювання сприяє переходу від пояснювальноспоглядального типу навчання до нового - активно-творчого. Крім цього, моделювання різноманітних графічних об'єктів і понять активізує просторову уяву, стимулює інтерес студентів до об'єкта вивчення.

Для перевірки засвоєння навчального матеріалу з відповідної теми передбачено перелік теоретичних і практичних запитань.

Кожний елемент змістового модуля $є$ не тільки носієм відповідної інформації, а й виконує специфічні функції (інформаційну, мотиваційну, освітню, розвивальну, контрольну, систематизуючу, стимулюючу, трансформаційну, координуючу, самоосвітню), які викладач реалізує у процесі навчання. 


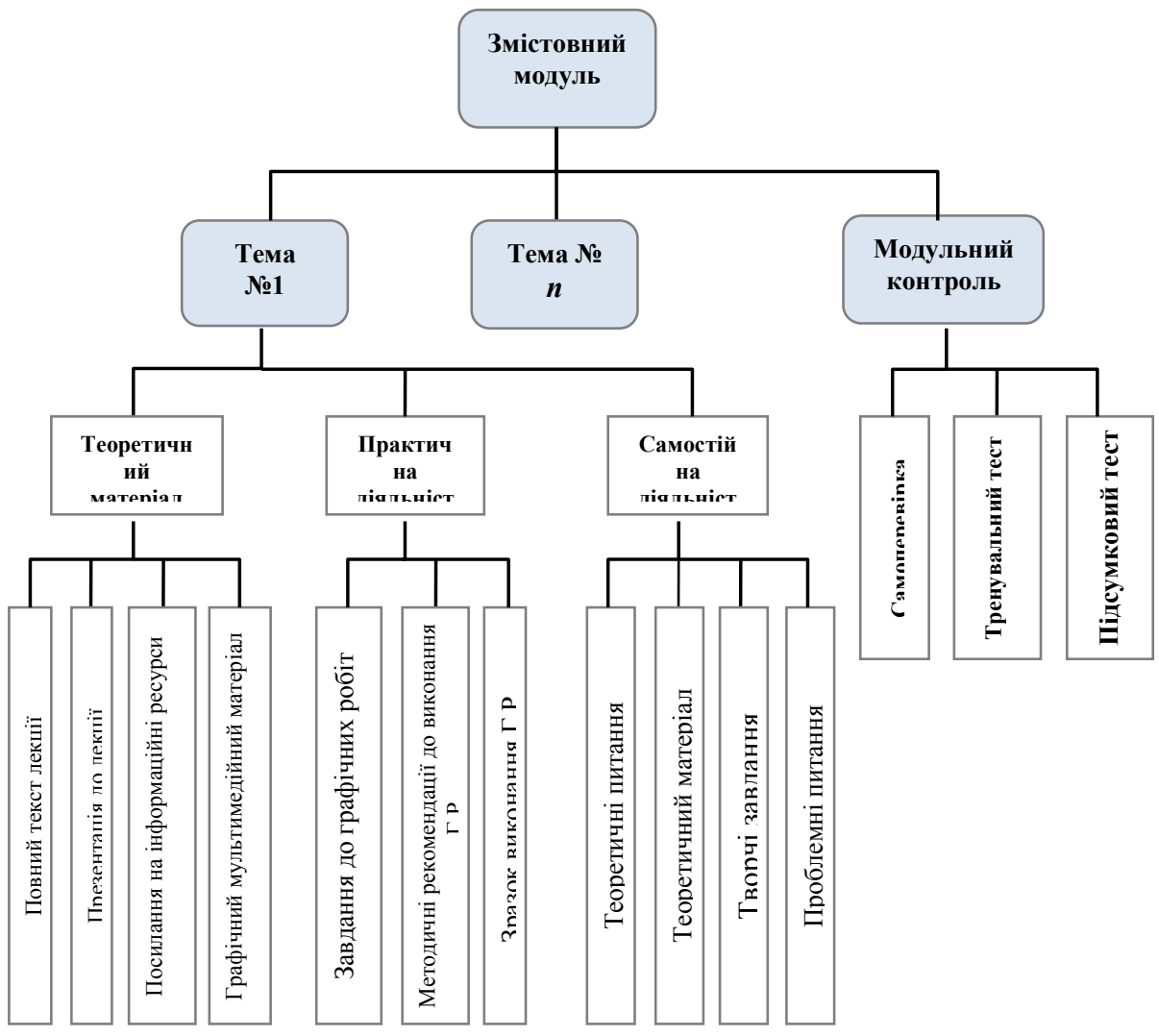

Рис. 2. Структура змістовного модуля

У контрольно-моніторинговому блоці містяться запитання для самоперевірки отриманих знань і набір тестових завдань, які дозволяють перевірити засвоєння знань, умінь і навичок з відповідного змістового модуля.

Розроблення й упровадження дистанційного курсу 3 креслення в навчальновиховний процес дає змогу:

- сформувати у студентів відповідний рівень графічної компетентності у процесі вивчення креслення;

- структурувати й візуалізувати зміст навчального матеріалу для більш ефективного його сприйняття студентами;

- підвищити мотивацію навчально-пізнавальної діяльності студентів;

- активізувати пізнавальну діяльність студентів у процесі вивчення креслення;

- підвищити якість засвоєння навчального матеріалу шляхом індивідуалізації процесу навчання;

- розвинути наочно-уявне, просторове, логічне й творче мислення студентів;

- надати можливість самостійного вивчення навчальної дисципліни.

Отже, упровадження дистанційного курсу у графічну підготовку майбутніх 
фахівців у Полтавському нафтовому геологорозвідувальному технікумі Полтавського національного технічного університету імені Юрія Кондратюка значно розширює можливості викладача, спрямовує студентів на свідоме засвоєння знань; сприяє розвитку їх пізнавальної активності, просторового й технічного мислення, і як наслідок формуванню професійних та особистісних якостей фахівця, що володіє політехнічним світоглядом, професійною мобільністю та конкурентоспроможністю, який достатньо швидко здатний адаптуватися до сучасних виробничих умов.

\section{Література}

1. Воронцова I. В. Педагогічні умови формування графічної компетентності майбутніх кваліфікованих робітників машинобудівного профілю : дис. ... канд. пед. наук : 13.00.04 / I. В. Воронцова. - К., 2014. - 369 с. 2. Професійна підготовка викладача-тьютора: теорія і методика: [навч.метод. посібник] / С. О. Сисоєва, В. В. Осадчий, К. П. Осадча. - Київ; Мелітополь: ТОВ «Видавничий будинок ММД», 2011. - 280 c. 3. Слободянюк О. В. Дистанційне навчання інженерній та комп'ютерній графіці : особливості методики викладання / О.В.Слободянюк; [редкол. І. А. Зязюн та ін.] // Сучасні інформаційні технології та інноваційні методики навчання в підготовці фахівців : методологія, теорія, досвід, проблеми : [зб. наук. пр.]. - Київ-Вінниця : ТОВ «Планер», 2010. - Вип. 24. - С.491-495. 4. Юсупова М. Ф. Застосування нових інформаційних технологій в графічній підготовці студентів вищих навчальних закладів: дис. ... канд. пед. наук: 13.00.02/ М. Ф. Юсупова. - Одеса, 2002. - 250 с. 5. Чередніченко Г. А. Інформаційні технології дистанційного навчання: перспективи та проблеми / Г. А. Чередніченко, І. П. Тригуб // Науковий вісник Національного університету біоресурсів і природокористування України: зб. наук. праць. - 2010. - Вип. 155. - Ч. 1. - С. 156-162.

УДК 378.147

Віма Гаманюк, Наталія Хорошилова

\section{ПРОБЛЕМИ МОДЕРНІЗАЦІЇ СИСТЕМИ ІНШОМОВНОЇ ПЕДАГОГІЧНОЇ ОСВІТИ В УКРАЇНI}

Гаманюк В. А., Хорошилова Н. В.Проблеми модернізації системи іншомовної педагогічної освіти в Україні.

Стаття присвячена аналізу актуальних на сьогодні загальних підходів, а також рамкових програм і нормативних документів у сфері іншомовної освіти і підготовки вчителів іноземних мов в Україні. У статті узагальнюються ключові положення документів та визначаються основні напрями й механізми модернізації іншомовної педагогічної освіти в Україні.

Ключові слова: система іншомовної освіти, педагогічна освіта, модернізація, рамкова програма.

Гаманюк В. А., Хорошилова Н. В. Проблемы модернизации системы иноязычного педагогического образования в Украине.

Статья посвящена анализу актуальных на сегодняшний день общих подходов, рамочных программ и нормативных документов в области иноязычного образования и подготовки учителей иностранных языков в Украине. В статье обобщаются ключевые положення документов и определяются основные направления и механизмы модернизации иноязычного педагогического образования в Украине.

Ключевые слова: система иноязычного образования, педагогическое образование, модернизация, рамочная программа. 